I N F ORM A T I R

Jurnal Informatika, Manajemen dan Komputer, Vol. 10 No. 2, Desember 2018

eISSN : 2580-3042

pISSN : 1979-0694

\title{
IMPLEMENTASI METODE SAW DALAM PEMILIHAN ALAT KONTRASEPSI PADA PUSKESMAS JAYA MUKTI
}

\author{
Mardiani $^{1}$, Elisawati ${ }^{2}$, Chandra Eri Firman ${ }^{3}$, Nurhadi $^{4}$ \\ ${ }^{1,2,4}$ Sekolah Tinggi Manajemen Informatika dan Komputer (STMIK) Dumai \\ ${ }^{3}$ Akademi Manajemen Informatika \& Komputer (AMIK) Dumai \\ Jl.Utama Karya Kel.Bukit Batrem Kec.Dumai Timur, Dumai-Riau 28811 \\ e-mail : mardianisisteminformasimalam@gmail.com
}

\begin{abstract}
ABSTRAK
Puskesmas Jaya Mukti merupakan tempat berkumpulnya orang sakit, melahirkan dan cek kesehatan. Di puskesmas jaya mukti terdapat beberapa bagian klinik, yaitu Poli Umum, Poli Lansia,Poli Gigi dan Poli KIA/K. Penelitian yang dilakukan pada Puskesmas Jaya Mukti Dumai, dimana permasalahan yang dijadikan dasar adalah banyak ibu-ibu pasangan usia subur kurang paham tentang pemilihan alat kontrasepsi apa yang cocok untuk digunakan bahkan ada yang enggan menggunakan alat kontrasepsi.Untuk mengatasi permasalahan tersebut maka digunakan metode SAW yang berguna dalam pemilihan alat kontrasepsi yang cocok bagi pengguna. Di dalam metode SAW menggunakan kriteria umur, berat badan, tekanan darah, riwayat penyakit dan jumlah anak. Dari kriteria tersebut di cari nilai tertinggi untuk mengetahui alat kontrasepsi yang cocok di gunakan bagi ibu-ibu pasangan usia subur. Sehingga metode SAW dapat memberikan informasi kepada Puskesmas Jaya Mukti dalam hal pemilihan alat kontrasepsi secara tepat dan akurat.
\end{abstract}

Kata kunci : Metode SAW, Alat Kontrasepsi, Reproduksi.

\section{PENDAHULUAN}

Puskesmas Jaya Mukti berada di Kelurahan Jaya Mukti Kecamatan Dumai Timur Kota Dumai. Puskesmas Jaya Mukti merupakan salah satu tempat pelayanan kesehatan bagi masyarakat Kota Dumai, terutama masyarakat Kelurahan Jaya Mukti. Adapun layanan kesehatan yang dilayani di Puskesmas Jaya Mukti adalah orang sakit, orang melahirkan, melayani konsultasi dan penggunaan alat kontrasepsi.

Dalam upaya meningkatkan pelayanan terhadap Keluarga Berencana (KB) yang digalakkan oleh pemerintah, Puskesmas Jaya Mukti menyediakan layanan khusus kepada masyarakat yang ingin konsultasi atau menggunakan alat kontrasepsi.

Manfaat penggunaan alat kontrasepsi adalah dapat mengatur kehamilan yang diinginkan, ibu dan bayi dapat lebih sehat karena risiko kehamilan dapat dihindari, meningkatkan kesejahteraan keluarga, menjaga keharmonisan keluarga karena masing - masing anggota keluarga mendapatkan waktu lebih banyak bersama, memberikan kesempatan pendidikan anak yang lebih baik. Untuk itu Puskesmas Jaya Mukti sering mengadakan sosialisasi mengenai alat kontrasepsi yang aman dan memberikan layanan konsultasi kepada ibu - ibu usia subur.

Usia ibu subur biasanya pada usia 10 tahun sampai usia 49 tahun. Ibu - ibu usia subur masih banyak yang ragu menggunakan alat kontrasepsi. Kurangnya pengetahuan ibu-ibu yang masih PUS (Pasangan Usia Subur) tentang pemilihan alat kontrasepsi banyak dipengaruhi oleh pendapat dimasyarakat yang beranggapan bahwa dengan menggunakan alat kontrasepsi ini banyak sekali efek samping yang merugikan kesehatan dan mengakibatkan banyak ibu-ibu yang ragu untuk memakai alat kontrasepsi, untuk itu masyarakat terutama ibu-ibu yang masih berstatus PUS haruslah lebih paham dan mengerti tentang penggunaan alat kontrasepsi yang ingin digunakan dan sebaiknya mempunyai kriteria dalam pemilihan alat kontrasepsi yang digunakan baik itu dari segi jangka waktu pemakaian, cara pemakaian maupun efek samping dari alat kontrasepsi yang di gunakan. 
INFORM A I I A

Jurnal Informatika, Manajemen dan Komputer, Vol. 10 No. 2, Desember 2018

eISSN : 2580-3042

pISSN : 1979-0694

Adapun metode dalam pembuatan aplikasi ini adalah Metode Simple Additive Weight $(S A W)$. Pendekatan metode ini kearah penentuan keputusan yang memiliki banyak kriteria / atribut penentu. Hal ini sesuai dengan aturan yang menjadi standar Puskesmas Jaya Mukti dalam menentukan keputusan, dimana ibu - ibu usia subur harus memenuhi beberapa syarat tertentu untuk dapat menggunakan alat kontrasepsi yang cocok atau sesuai

\section{a. Alat Kontrasepsi}

Alat Kontrasepsi adalah alat yang di gunakan sebagai alat untuk mencegah terjadinya pembuahan. Untuk keperluan itu, biasanya kontrasepsi ini di lakukan dengan beberapa alat dan juga cara.(TIM BKKBN, 2014)

\section{b. Context Diagram}

Context Diagram merupakan level teratas (top Level) dari diagram arus data. Context diagram menggambarkan hubungan input/output antara sistem dengan dunia luarnya (kesatuan luar). (Ismael, 2017)

Tabel 1. Context Diagram

\begin{tabular}{|l|c|}
\hline Gambar & Keterangan \\
\hline & Proses \\
\hline$\longleftarrow$ & Arus \\
\hline & External entity \\
\hline
\end{tabular}

Sumber : (Ismael, 2017)

\section{c. Data Flow Diagram}

Data Flow Diagram merupakan peralatan yang berfungsi untuk menggambarkan secara rinci mengenai sistem sebagai jaringan kerja antar dari dan ke mana data mengalir serta penyimpanannya. (Rohayati (1), 2016)

Tabel 2. Data Flow Diagram

\begin{tabular}{|l|l|}
\hline Simbol & \multicolumn{1}{|c|}{ Keterangan } \\
\hline & $\begin{array}{l}\text { Simbol entitas eksternal/ } \\
\text { terminator menggambarkan } \\
\text { asal atau tujuan data diluar } \\
\text { system }\end{array}$ \\
\hline & $\begin{array}{l}\text { Simbol lingkaran } \\
\text { menggambarkan entitas atau } \\
\text { proses dimana aliran data } \\
\text { masuk ditransformasikan ke } \\
\text { aliran data keluar }\end{array}$ \\
\hline$\longrightarrow$ & $\begin{array}{l}\text { Simbol aliran data } \\
\text { menggambarkan aliran data }\end{array}$ \\
\hline Sumber: (Rohayati (1), 2016) \\
Simbol file menggambarkan \\
\hline
\end{tabular}

\section{d. Visual Basic}

Visual Basic adalah bahasa pemograman generasi ke tiga dari Microsoft dengan IDE (Integrated Development Environment) atau pemograman pengembangan terpadu, visual basic di buat dan di rancang untuk mudah di gunakan baik oleh progremer pemula sekalipun. (Atmoko, 2013)

\section{e. Aliran Sistem Informasi}

Aliran Sistem Informasi (ASI) merupakan bagan yang menunjukan arus pekerjaan serta keseluruhan dari sistem. (Ismael, 2017)

\section{f. Metode SAW}

Metode SAW adalah mencari penjumlahan terbobot dari rating kinerja pada setiap alternatif pada semua atribut 
IN F O R M A T I A

Jurnal Informatika, Manajemen dan Komputer, Vol. 10 No. 2, Desember 2018

eISSN : 2580-3042

pISSN : 1979-0694

$R i j\left\{\begin{array}{c}\frac{X i j}{M a x X i j} \text { Jika j adalah atribut ............(1) } \\ \text { keuntungan (benefit) } \\ \frac{\text { Min Xij }}{X i j} \text { Jika } j \text { adalah atribut ............ (2) } \\ \text { biaya (cost) }\end{array}\right.$

Dimana :

$\mathrm{Rij} \quad=$ Rating kinerja ternormalisasi

Maxij $=$ Nilai maksimum dari setiap baris dan kolom

Minij $=$ Nilai minimum dari setiap baris dan kolom

Xij $\quad=$ Baris dan kolom dari matriks

Dengan Rij adalah rating kinerja ternormalisasi dari alternatif $\mathrm{Ai}$ pada atribut $\mathrm{Cj} ; \mathrm{i}=1,2, \ldots \mathrm{m}$ dan $\mathrm{j}=1,2, \ldots, \mathrm{n}$.

Nilai Vi yang lebih besar mengindikasikan bahwa alternatif Ai lebih terpilih.

Dimana :

$\mathrm{Vi}=$ Nilai akhir dari alternatif

$\mathrm{Wi}=$ Bobot yang telah ditentukan

Rij $=$ Normalisasi matriks

Nilai yang lebih besar mengindikasikan bahwa alternatif lebih terpilih.

Ada beberapa langkah dalam penyelesaian metode Simple Additive Weight (SAW) adalah sebagai berikut:

1. Menentukan kriteria-kriteria yang dijadikan acuan dalam pendukung keputusan yaitu $\mathrm{Ci}$.

2. Menentukan rating kecocokan setiap alternatif pada setiap kriteria.

3. Membuat matriks keputusan berdasarkan kriteria (Ci).

4. Kemudian melakukan normalisasi matriks berdasarkan persamaan yang disesuaikan dengan jenis atribut (atribut keuntungan maupun atribut biaya) sehingga diperoleh matriks ternormalisasi R.

5. Hasil akhir diperoleh dari proses perangkingan yaitu penjumlahan dari perkalian matriks ternormalisasi $\mathrm{R}$ dengan vector bobot sehingga diperoleh nilai. (Frieyadie, 2016).

\section{g. Entity Relationship Diagram (ERD)}

Entity Relationship Diagram (ERD) adalah suatu diagram yang digunakan untuk memodelkan struktur data dan hubungan antar data. (Rohayati (1), 2016)

\section{h. Crystal Report}

Crystal Report Merupakan komponen yang akan kita gunakan untuk membuat report atau laporan dari program yang akan kita buat, agar

dapat dipahami oleh pengguna, report tersebut diambil dari kumpulan data dari table yang tersimpan didalam database sql server. (Atmoko, 2013)

\section{i. SQL}

SQL merupakan sebuah relasional database management sisitem (RDBMS) buatan Microsoft, yang di rancang unt mendukung program dengan arsitektur client/server, dan informasi di gunakan bersama-sama oleh pengguna yang menjalankan program di dalam computer yang di sebut client. (Atmoko, 2013)

\section{METODOLOGI PENELITIAN}

Kerangka penelitian yang digunakan dalam penelitian ini adalah sebagai berikut :

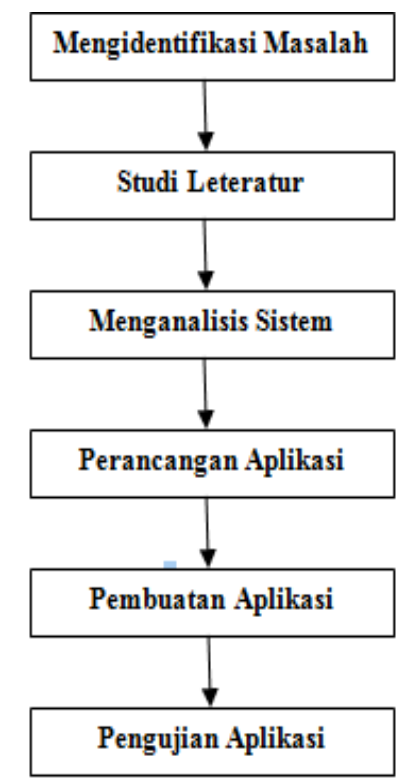

Gambar 1 : Kerangka Penelitian

Berdasarkan gambar 1 dapat dijelaskan bahwa:

1. Mengidentifikasi Masalah

Pada tahap ini dilakukan peninjauan terhadap masalah yang akan di teliti untuk memahami pemilihan alat kontrasepsi.

2. Studi Literatur

Studi literature dilakukan di pustaka untuk mengumpulkan keterangan berdasarkan referensi, buku-buku, jurnal, dan yang berkaitan dengan analisa perancangan system informasi, agar data yang di dapatkan bisa dijadikan acuan untuk menyelesaikan permasalahan dalam studi kasus ini.

3. Menganalisis Masalah

Analisis masalah pada penelitian ini dilakukan dengan metode dekriptif dimana data pada metode ini dikumpulkan, disusun, 
I N F O R M A I I A

Jurnal Informatika, Manajemen dan Komputer, Vol. 10 No. 2, Desember 2018

eISSN : 2580-3042

pISSN : 1979-0694

dikelompokkan, dan dianalisa sehingga diperoleh beberapa gambaran yang jelas pada permasalah yang dibahas pada Puskesmas Jaya Mukti.

4. Perancangan Aplikasi

Perancangan sistem pada tahap ini dilakukan proses desain sistem di mulai dengan penyajian basis data, perancangan aliran sistem informasi, DFD, context diagram, ERD, desain input, desain output dan hasil analisis data-data tersebut digunakan untuk membentuk suatu aplikasi baru yang telah dirancang.

5. Pembuatan Aplikasi

Setelah tahapan perancangan aplikasi dilakukan maka langkah selanjutnya adalah pembuatan aplikasi untuk menjalankan operasi komputer dengan menggunakan bahasa pemograman VB 6.0 berbentuk desktop.

6. Pengujian Aplikasi

Setelah aplikasi yang dirancang telah selesai dibuat maka perlu dilakukan pengujian apakah aplikasi ini bisa berjalan sesuai dengan yang telah direncanakan dan sesuai dengan tujuan penelitian.

Pengujian pertama yang dilakukan pada aplikasi ini apakah sudah berjalan dengan baik dan menu - menu sudah bekerja dengan baik. Pengecekan dilakukan disetiap form untuk mengetahui apakan ada kesalahan atau error yang terjadi, jika terdapat kesalahan maka aplikasi akan dilakukan perbaikan sehingga aplikasi tersebut dapat bekerja secara optimal dan sesuai dengan tujuan penelitian.

3. HASIL DAN PEMBAHASAN

a. Perhitungan Metode SAW

1. Perhitungan Manual

Berdasarkan dari penelitian yang dilakukan penulis, berikut penerapan dari SPK yang digunakan dalam pemilihan alat kontrasepsi pada Puskesmas Jaya Mukti Dumai menggunakan Metode Simple Additive Weighting.

a. Alternatif penggunaan alat kotrasepsi berdasarkan jumlah pembobotan penilaian

Pada deskripsi urutan penilaain penggunaan alat kontrasepsi, penulis melakukan analisis terhadap 3 jenis alat kontrasepsi sebagai sampel pada penelitian ini yaitu:

1. Suntik

2. Implan

3. IUD

\section{Kriteria Penilaian}

Adapun kriteria sebagai perbandingan adalah seperti dibawah ini :

1. Umur (C1)

2. Berat Badan $(\mathrm{C} 2)$

3. Tekanan Darah (C3)

4. Riwayat Penyakit (C4)

5. Jumlah Anak (C5)

Dari masing-masing kriteria tersebut memiliki sub kriteria yang akan ditentukan bobotbobotnya. Pada bobot terdiri dari lima bilangan, yaitu baik sekali, baik, sedang, cukup, dan rendah seperti terlihat pada tabel 3 .

Tabel 3. Tabel Bobot

\begin{tabular}{|c|c|}
\hline Kriteria & Nilai \\
\hline Baik Sekali & 1 \\
\hline Baik & 0,75 \\
\hline Sedang & 0,50 \\
\hline Cukup & 0,25 \\
\hline Rendah & 0,15 \\
\hline
\end{tabular}

Berdasarkan kriteria dan rating kecocokan setiap alternatif pada setiap kriteria yang telah ditentukan, selanjutnya penjabaran bobot setiap kriteria.

Tabel 4.tabel umur

\begin{tabular}{|c|c|c|}
\hline No & Kriteria Berdasarkan Umur & Nilai \\
\hline 1 & 18 tahun $\leq$ Baik Sekali $\leq 25$ & 1 \\
\hline 2 & $>=24$ Tahun $<30$ Tahun & 0,75 \\
\hline 3 & $>=31$ Tahun $<35$ Tahun & 0,50 \\
\hline 4 & $>=36$ Tahun $<40$ Tahun & 0,25 \\
\hline 5 & $>=41$ Tahun & 0,15 \\
\hline
\end{tabular}

Tabel 5.tabel berat badan

\begin{tabular}{|c|c|c|}
\hline No & Berat Badan & Nilai \\
\hline 1 & $45 \mathrm{Kg} \leq$ Baik Sekali $\leq 54,9$ & 1 \\
\hline 2 & $>=55 \mathrm{Kg}<65,9 \mathrm{Kg}$ & 0,75 \\
\hline 3 & $>=66 \mathrm{Kg}<75 \mathrm{Kg}$ & 0,50 \\
\hline 4 & $>=76 \mathrm{Kg}<85 \mathrm{Kg}$ & 0,25 \\
\hline 5 & $>=86 \mathrm{Kg}$ & 0,15 \\
\hline
\end{tabular}

Tabel 6.tabel tekanan darah

\begin{tabular}{|c|c|c|}
\hline Kriteria & Tekanan Darah & Nilai \\
\hline Baik Sekali & $100 / 130 \mathrm{Hg} \leq$ Baik Sekali & 1 \\
\hline Baik & $>=95 \mathrm{Hg}<120 \mathrm{Hg}$ & 0,75 \\
\hline
\end{tabular}


INFORM T I K A

Jurnal Informatika, Manajemen dan Komputer, Vol. 10 No. 2, Desember 2018

eISSN : 2580-3042

pISSN : 1979-0694

\begin{tabular}{|c|c|c|}
\hline Sedang & $>=90 \mathrm{Hg}<110 \mathrm{Hg}$ & 0,50 \\
\hline Cukup & $>=85 \mathrm{Hg}<100 \mathrm{Hg}$ & 0,25 \\
\hline Rendah & $>=80 \mathrm{Hg}<90 \mathrm{Hg}$ & 0,15 \\
\hline
\end{tabular}

\begin{tabular}{|c|c|c|c|c|c|}
\hline Siti & 43 & 86 & 80 & $\begin{array}{c}\text { Tidak } \\
\text { Memiliki } \\
\text { Riwayat } \\
\text { Anisa }\end{array}$ & 6 \\
Penyakit & \\
\hline
\end{tabular}

Tabel 7.tabel riwayat penyakit

\begin{tabular}{|c|c|c|}
\hline Kriteria & Riwayat Penyakit & Nilai \\
\hline Baik Sekali & Tidak memiliki Riwayat & 1 \\
\hline Baik & Tidak memiliki penyakit & 0,75 \\
\hline Sedang & Tidak ada penyakit akut, dan & 0,50 \\
\hline Cukup & Obesitas, Punya penyakit & 0,25 \\
\hline Rendah & $\begin{array}{c}\text { Obesitas,Akut, dan memiliki } \\
\text { penyakit menular dan } \\
\text { keputihan }\end{array}$ & 0,15 \\
\hline
\end{tabular}

Tabel 8.tabel jumlah anak

\begin{tabular}{|c|c|c|}
\hline Nomor & $\begin{array}{c}\text { Jumlah Anak } \\
\text { Nilai }\end{array}$ & \\
\hline 1 & $\begin{array}{c}1 \text { Orang } \leq \text { Baik Sekali } \leq 2 \\
\text { Orang }\end{array}$ & 1 \\
\hline 2 & 2 Orang $\leq$ Baik $\leq 3$ Orang & 0,75 \\
\hline 3 & 3 Orang $\leq$ Sedang $\leq 4$ Orang & 0,50 \\
\hline 4 & 4 Orang $\leq$ Cukup $\leq 5$ Orang & 0,25 \\
\hline 5 & Rendah $\geq 6$ Orang & 0,15 \\
\hline
\end{tabular}

Berikut ini adalah contoh tabel kasus dari perhitungan SAW

Tabel 9.tabel data pasien

\begin{tabular}{|c|c|c|c|c|c|}
\hline Nama & Umur & $\begin{array}{c}\text { Berat } \\
\text { Badan }\end{array}$ & $\begin{array}{c}\text { Tekanan } \\
\text { Darah }\end{array}$ & $\begin{array}{c}\text { Riwayat } \\
\text { Penyakit }\end{array}$ & $\begin{array}{c}\text { Juml } \\
\text { ah } \\
\text { Anak }\end{array}$ \\
\hline Juliana & 25 & 65 & 110 & $\begin{array}{c}\text { Memiliki } \\
\text { Alergi } \\
\text { dan } \\
\text { pernah } \\
\text { operasi }\end{array}$ & 2 \\
\hline $\begin{array}{c}\text { Sri } \\
\text { Dewi }\end{array}$ & 32 & 92 & 95 & $\begin{array}{c}\text { Tidak } \\
\text { Memiliki } \\
\text { Riwayat } \\
\text { Penyakit }\end{array}$ & 4 \\
\hline
\end{tabular}

Berdasarkan data alat kontrasepsi yang digunakan oleh pasien diatas dapat dibentuk matriks keputusan $\mathrm{x}$, sebagai berikut :

Tabel 10.tabel rating kecocokan dari setiap altermatif pada setiap kriteria

\begin{tabular}{|c|c|c|c|c|c|}
\hline \multirow{2}{*}{$\begin{array}{c}\text { Alterna } \\
\text { tif }\end{array}$} & \multicolumn{5}{|c|}{ Kriteria } \\
\cline { 2 - 6 } & C1 & C2 & C3 & C4 & C5 \\
\hline A1 & 0,75 & 0,75 & 1 & 0,50 & 0,75 \\
\hline A2 & 0,50 & 0,15 & 0,75 & 1 & 0,25 \\
\hline A3 & 0,15 & 0,15 & 0,15 & 1 & 0,15 \\
\hline
\end{tabular}

Pengambilan keputusan memberikan bobot, berdasarkan tingkat kepentingan masing-masing kriteria yang dibutuhkan sebagai berikut :

Rangking bobot : $\mathrm{W}=[0,30,0,25,0,20,0,15,0,10]$ Membuat matriks keputusan $\mathrm{x}$, dibuat dari tabel kecocokan sebagai berikut :

$X=\left\{\begin{array}{ccccc}0,75 & 0,75 & 1 & 0,50 & 0,75 \\ 0,50 & 0,15 & 0,75 & 1 & 0,25 \\ 0,15 & 0,15 & 0,15 & 1 & 0,15\end{array}\right\}$

Karena setiap nilai yang di berikan pada setiap alternatif di setiap kriteria merupakan nilai kecocokan (nilai terbesar adalah terbaik) maka semua kriteria yang di berikan di asumsi sebagai kriteria keuntungan.

Pertama dilakukan normalisasi matriks $\mathrm{X}$ untuk menghitung nilai masing-masing kriteria sebagai berikut:

$$
\begin{aligned}
& R 11=\frac{0,75}{\operatorname{Max}(0,75,0,50,0,15)}=\frac{0,75}{0,75}=1 \\
& R 12=\frac{0,75}{\operatorname{Max}(0,75,0,15,0,15)}=\frac{0,75}{0,75}=1 \\
& R 13=\frac{1}{\operatorname{Max}(1,0,75,0,15)}=\frac{1}{1}=1 \\
& R 14=\frac{0,50}{\operatorname{Max}(0,50,1,1)}=\frac{0,50}{1}=0,5 \\
& R 15=\frac{0,75}{\operatorname{Max}(0,75,0,25,0,15)}=\frac{0,75}{0,75}=1 \\
& R 21=\frac{0,50}{\operatorname{Max}(0,75,0,50,0,15)}=\frac{0,50}{0,75}=0,66 \\
& R 22=\frac{0,15}{\operatorname{Max}(0,75,0,15,0,15)}=\frac{0,15}{0,75}=0,2 \\
& R 23=\frac{0,75}{\operatorname{Max}(1,0,75,0,15)}=\frac{0,75}{1}=0,75
\end{aligned}
$$


INFORM T I K

Jurnal Informatika, Manajemen dan Komputer, Vol. 10 No. 2, Desember 2018

eISSN : 2580-3042

pISSN : 1979-0694

$$
\begin{aligned}
& R 24=\frac{1}{\operatorname{Max}(0,50,1,1)}=\frac{1}{1}=1 \\
& R 25=\frac{0,25}{\operatorname{Max}(0,75,0,25,0,15)}=\frac{0,25}{0,75}=0,33 \\
& R 31=\frac{0,15}{\operatorname{Max}(0,75,0,50,0,15)}=\frac{0,15}{0,75}=0,2 \\
& R 32=\frac{0,15}{\operatorname{Max}(0,75,0,15,0,15)}=\frac{0,15}{0,75}=0,2 \\
& R 33=\frac{0,15}{\operatorname{Max}(1,0,75,0,15)}=\frac{1,15}{1}=0,15 \\
& R 34=\frac{1}{\operatorname{Max}(0,50,1,1)}=\frac{1}{1}=1 \\
& R 35=\frac{0,15}{\operatorname{Max}(0,75,0,25,0,15)}=\frac{0,15}{0,75}=0,2
\end{aligned}
$$

Kedua, membuat normalisasi matriks $\mathrm{R}$ yang diperoleh dari hasil normalisasi matriks $\mathrm{R}$ sebagai berikut:

$$
\mathrm{R}=\left\{\begin{array}{ccccc}
1 & 1 & 1 & 0,5 & 1 \\
0,66 & 0,2 & 0,75 & 1 & 0,33 \\
0,2 & 0,2 & 0,15 & 1 & 0,2
\end{array}\right\}
$$

Selanjutnya melakukan proses Perangkingan di mana akan dibuat perkalian matriks $\mathrm{W} * \mathrm{R}$ dan penjumlahan hasil perkalian untuk memperoleh alternatif terbanyak dengan melakukan kelayakan nilai terbesar sebagai berikut:

$$
\begin{aligned}
& \mathrm{V} 1=(0,30 * 1)+(0,25 * 1)+(0,20 * 1)+( \\
& 0,15 * 0,5)+(0,10 * 1) \\
& \quad=0,3+0,25+0,2+0,075+0,1 \\
& \quad=0,925 \\
& \begin{aligned}
\mathrm{V} 2 & =(0,30 * 0,66)+(0,25 * 0,2)+(0,20 * 0,75)+ \\
(0,15 & * 1)+(0,10 * 0,33) \\
& =0,198+0,05+0,15+0,15+0,033 \\
& =0,581 \\
\mathrm{~V} 3 \quad & =(0,30 * 0,2)+(0,25 * 0,2)+(0,20 * 0,15)+ \\
(0,15 & * 1)+(0,10 * 0,2) \\
& =0,06+0,05+0,03+0,15+0,02 \\
& =0,31
\end{aligned}
\end{aligned}
$$

Dari hasil perhitungan, V1 yang lebih besar mengidentifikasi Alternatif A1 merupakan Alternatif terbaik. Hasil perhitungan Terbesar ada pada V1 yaitu Juliana dengan Menggunakan Alat Kontrasepsi Suntik KB. Sehingga dapat di jadikan alternatif dalam pemilihan alat kontrasepsi pada Puskesmas Jaya Mukti sebagai alternatif yang terpilih dan terbaik.

\section{b. Contex Diagram}

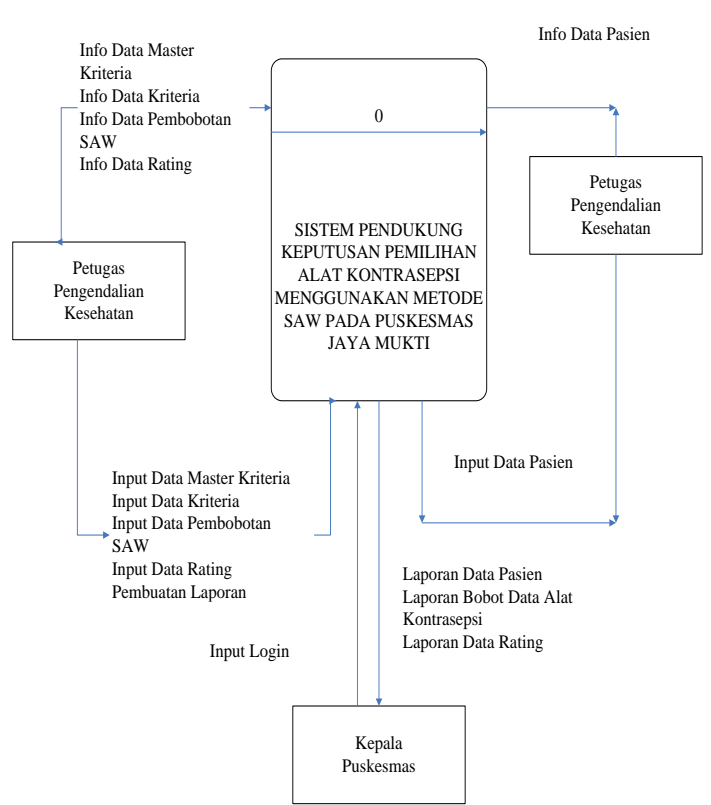

Gambar 2. Contex Diagram

\section{c. Entity Relation Diagram}

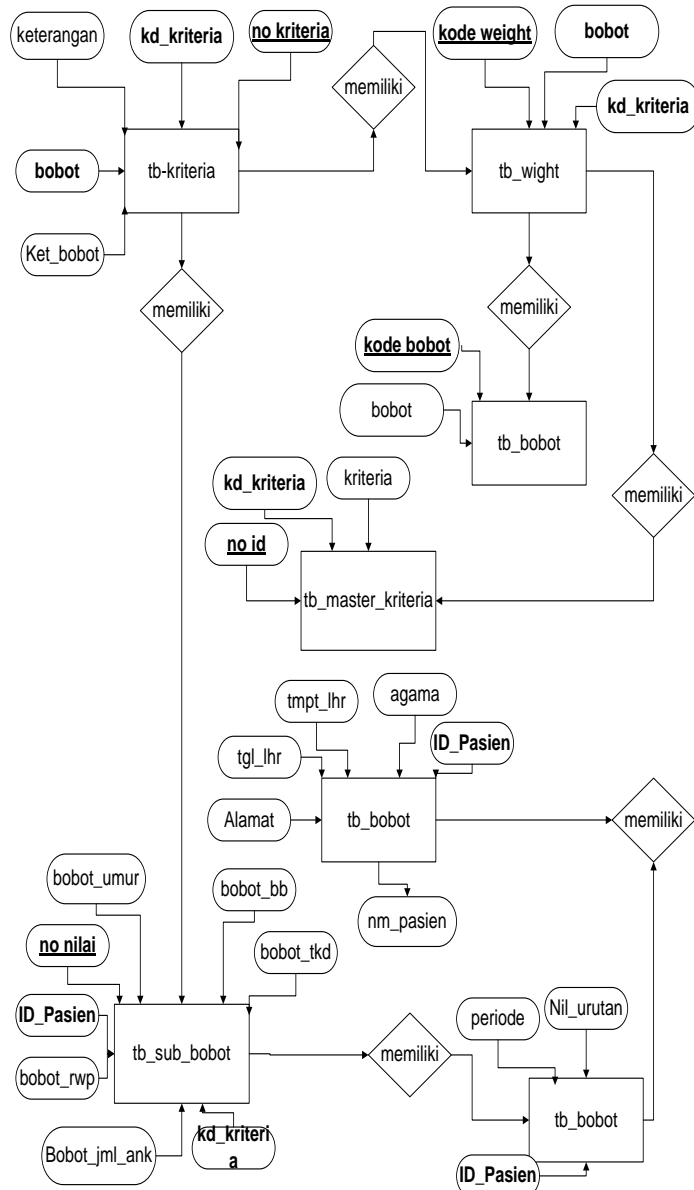

Gambar 3. ERD (Entity Relationship Diagram) 
I N F ORM A T I R

Jurnal Informatika, Manajemen dan Komputer, Vol. 10 No. 2, Desember 2018

eISSN : 2580-3042

pISSN : 1979-0694

\section{d. Data Flow Diagram}

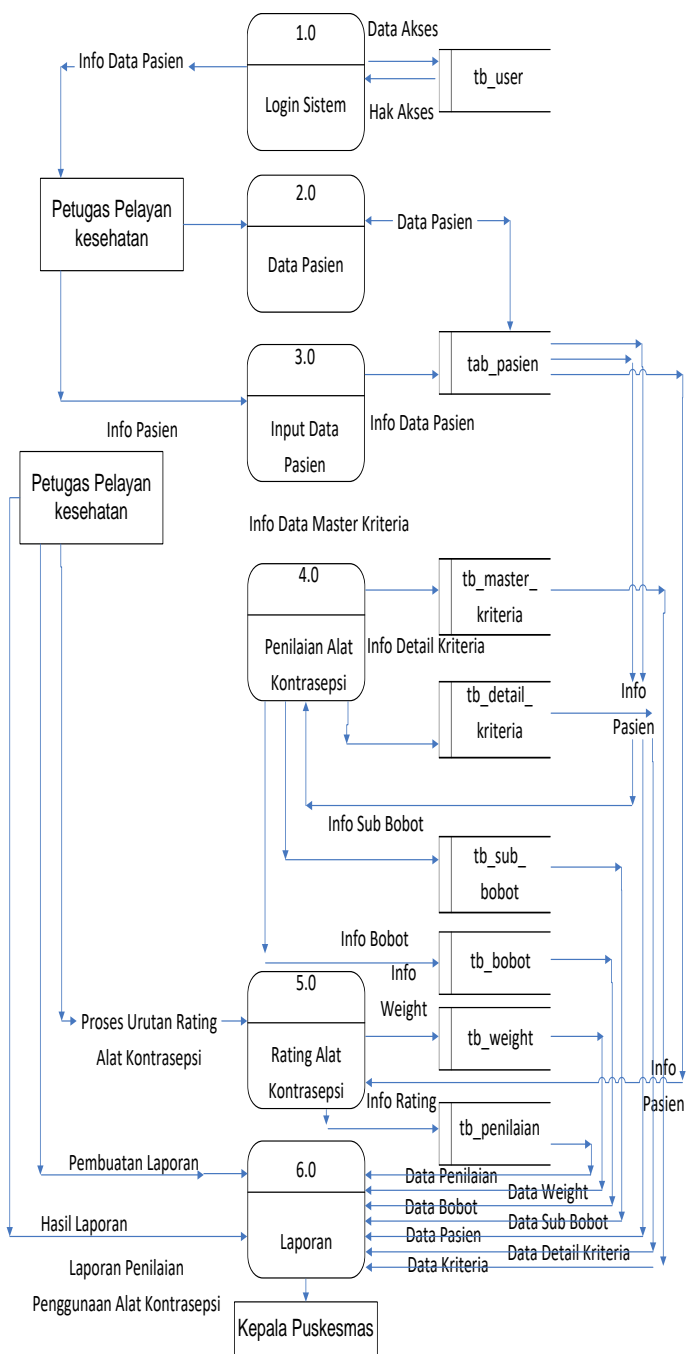

Gambar 4. DFD (Data Flow Diagram)

\section{KESIMPULAN}

Dari uraian pada bab-bab yang sudah dibahas sebelumnya dapat ditarik kesimpulan bahwa implementasi metode $S A W$ dapat meningkatkan minat masyarakat terutama ibu-ibu pasangan usia subur (PUS) dalam melaksanakan program Keluarga Berencana (KB), Serta dapat menambah wawasan masyarakat dalam menjalankan Genre (Generasi Berencana) di masyarakat yang akan datang.

\section{REFERENSI}

atmoko, Eko Hari. 2013. Program Akuntansi Beserta Manajemen Aset Menggunakan $\mathrm{Vb}$ Dan Sql Server. Jakarta: Pt Elex Media Komputindo. Http:/Elexmedia.Co.Id.

Frieyadie. 2016. "Dalam Sistem Pendukung

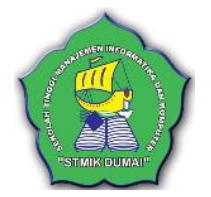

Keputusan Promosi." Metode yang digunakan dalam menentukan promosi Promosi ini Simple Additive Weight (SAW). Di mana metode ini adalah metode penghitungan tertimbang atau metode yang menyediakan kriteria tertentu yang berbobot sehingga setiap nilai jumlah dari bobot dari has (1): 37-45.

Hartini, Dwi Citra, Endang Lestari Ruskan, and Ali Ibrahim. 2013. "Sistem Pendukung Keputusan Pemilihan Hotel Di Kota Palembang Dengan Metode Simple Additive Weighting (SAW)." Jurnal Sistem Informasi (JSI) 5(1): 546-65.

Ilmiah, Teknologi. 2014. "Sistem Pendukung Keputusan Dengan Metode Simple Additive Weighting Untuk Menentukan Dosen." : 11-15.

Ismael. 2017. "Rancang Bangun Sistem Informasi Penyaluran Semen Padang Untuk Daerah Bengkulu Selatan Di Cv. Mutia Bersaudara." Jurnal EdikInformatika Penelitian Bidang Komputer Sains dan Pendidikan Informatika.

Mardheni Muhammad, Novi Safriadi, Narti Prihartini. 2017. "Implementasi Metode Simple Additive Weighting ( Saw ) Pada Sistem Pendukung Keputusan Dalam Menentukan Prioritas Perbaikan Jalan." Jurnal Media Informatika Budidarma ISSN 2548-8368 5(2): 49-53.

ridwanaz. 2012. "Definisi, Jenis, Dan Contoh Alat Kontrasepsi Serta Keuntungan Kekurangan."

http://ridwanaz.com/kesehatan/definisijenis-dan-contoh-alat-kontrasepsi-sertakeuntungan-kekurangan/.

Rohayati (1), Agus Irwandi HJ (2) Abstrak. 2016. "Perancangan Dan Implementasi Sistem Informasi Inventaris Laboratorium." ISSN 1412-5609 (Print) ISSN 2443-1060 (Online) Jurnal INTEKNA, Volume 16, No. 2, November 2016: 101-200 PERANCANGAN.

Sonata, Fifin. 2016. "Implementasi Metode Simple Additive Weighting (Saw) Dengan Proses Fuzzifikasi Dalam Penilaian Kinerja Dosen." Jurnal Teknologi Informasi dan Komunikasi.

TIM BKKBN. 2014. Metode Konttrasepsi Jangka Panjang (MKJP). Jakarta. 